\title{
$1952-2011$ 年鄱阳湖枯水变化分析”
}

\author{
闵 寒 $^{1}$, 占腊生 ${ }^{2}$ \\ ( 1 : 江西省鄱阳湖水文局, 九江 332800$)$ \\ ( 2 : 景德镇陶瓷学院, 景德镇 333001)
}

\begin{abstract}
摘 要: 利用鄱阳湖区 1952-2011 年水文监测资料,分析鄱阳湖近 $60 \mathrm{a}$ 来枯水特征及其变化规律; 从流域降水、五河来 水、长江上中游来水、湖盆形态等方面的变化,探讨鄱阳湖枯水变化原因. 结果表明,进人 21 世纪后的近 $11 \mathrm{a}$ 鄱阳湖枯水 程度显著加剧,尤其是近 $5 \mathrm{a}$ 来最低水位不断被刷新; 造成鄱阳湖枯水变化的最主要原因是流域降水和五河来水的相应 变化, 其次是长江上中游来水变化, 湖盆形态变化对于近 $10 \mathrm{a}$ 来枯水加剧起到了推波助澜的作用; 三峡大坝蓄水以后, 长 江上中游来水变化对鄱阳湖枯水变化的控制作用呈现逐渐加强态势.
\end{abstract}

关键词: 枯水; 原因; 鄱阳湖

\section{Characteristics of low-water level changes in Lake Poyang during 1952-2011}

\author{
MIN Qian ${ }^{1} \&$ ZHAN Lasheng ${ }^{2}$ \\ ( 1 :Poyanghu Hydrology Bureau of Jiangxi Province, Jiujiang 332800, P. R. China) \\ (2: Jingdezhen Ceramic Institute, Jingdezhen 333001, P. R. China)
}

\begin{abstract}
Using the hydrology monitoring data in Lake Poyang area during 1952-2011, the characteristics and variations of lowwater level in Lake Poyang in recent 60 years were analyzed. Possible mechanisms for the variations of low-water level changes in Lake Poyang were discussed, i. e. influences from precipitation within the basin, inflows from the five rivers within the catchment, and from the middle and lower reaches of Yangtze River, and lake basin topography. The results showed that the low-water level status was aggravating in the last 11 years, especially in the last 5 years, since the inflows from the five rivers were decreased due to less precipitation in Lake Poyang Basin. Secondly, the control of low-water level in Lake Poyang by inflows from the middle and lower reaches of Yangtze River was strengthened during the past 10 years, especially the effects were enhanced after the operation of the Three-Gorge Dam.
\end{abstract}

Keywords: Low-water level; reason; Lake Poyang

\section{1 枯水标准与统计方法}

\section{1 枯水统计标准}

对于湖泊枯水等级的划分并没有统一的标准. 鄱阳湖具有 “高水是湖,低水似河” 的水文特征, 枯水时期 湖面落差较大 ${ }^{[1-2]}$,主航道底部高程和两侧洲滩高程沿程变化很大. 根据 2010 年鄱阳湖基础地理测量 DEM 成果,鄱阳湖自南向北主航道底部高程和两侧洲滩高程沿程变化的一致性较好,且与最枯水时期水位沿程 变化较为一致,因此我们选择以主航道内水面高程与两侧岸边高程差为枯水等级划分标准.

都昌水文站位于鄱阳湖中部, 为鄱阳湖流域代表水文站. 该站附近主航道两侧岸边高程一般比多年平 均水位低 $1 \mathrm{~m}$ 左右. 依据历年枯水期水位时间分布和主航道两侧洲滩高程, 结合沿湖城乡取水口调查, 提出 鄱阳湖枯水划分标准为 (1952-2010 年平均水位 $13.81 \mathrm{~m}$,冻结基面, $-1.86 \mathrm{~m}$ 为 1985 年高程基准,下同) : (1) 一般枯水: $11.8 \mathrm{~m}<H \leqslant 12.8 \mathrm{~m}$, 湖区部分排灌站取水困难; (2) 中度枯水: $10.8 \mathrm{~m}<H \leqslant 11.8 \mathrm{~m}$, 湖区大

* 国家自然科学基金项目 (11073010) 和江西省水利科研项目(KT201016)联合资助. 2011-11-30 收稿;2012-0320 收修改稿. 闵骞,男,1958 年生,工程师;E-mail: minqian1958@163.com. 
部分排灌站取水困难, 部分区域航运受阻; (3) 较重枯水: $9.8 \mathrm{~m}<H \leqslant 10.8 \mathrm{~m}$, 湖区绝大多数排灌站取水困 难, 湖边少数自来水厂取水困难, 部分区域航运严重受阻; (4) 严重枯水: $8.8 \mathrm{~m}<H \leqslant 9.8 \mathrm{~m}$, 湖区排灌站几 乎无法取水,部分自来水厂取水困难,多数区域航运严重受阻; (5) 极度枯水: $H \leqslant 8.8 \mathrm{~m}$, 湖边多数自来水厂 取水困难,绝大多数区域航运严重受阻.

\section{2 枯水统计方法}

一般将每年 4 月至次年 3 月作为一个水文年. 在鄱阳湖,这种划分方法只适用于洪水统计分析 ${ }^{[34]}$; 而不 适用于枯水统计分析 ${ }^{[5-6]}$. 为便于鄱阳湖枯水水情的水文统计分析, 本文将每年 7 月至次年 6 月作为枯水水 文统计分析年.

\section{2 枯水程度及其变化}

\section{1 年最低水位}

据统计, 1952-2010 年年最低水位的平均值为 $9.61 \mathrm{~m}$, 最高值为 $11.67 \mathrm{~m}$ (2002 年), 最低值为 $7.99 \mathrm{~m}$ (2008 年),变幅为 $3.68 \mathrm{~m}$, 远小于年最高水位变幅 $(6.55 \mathrm{~m})$, 也小于年平均水位变幅 $(4.48 \mathrm{~m}) .1980 \mathrm{~s}$ 至 今, 鄱阳湖年最低水位呈下降趋势, 近 $10 \mathrm{a}(2001-2010$ 年) 为鄱阳湖年最低水位最低时期 (表 1).

表 $11952-2010$ 年都昌水文站年最低水位多年变化统计

Tab. 1 Statistics of yearly mean lowest water level at Duchang Station during 1952-2010

\begin{tabular}{cccccccc}
\hline 水位 & $1952-1960$ & $1961-1970$ & $1971-1980$ & $1981-1990$ & $1991-2000$ & $2001-2010$ & $1952-2010$ \\
\hline 年最低水位 $/ \mathrm{m}$ & 9.64 & 9.41 & 9.54 & 9.96 & 10.07 & 9.02 & 9.61 \\
年平均水位 $/ \mathrm{m}$ & 13.90 & 13.77 & 13.71 & 14.15 & 14.19 & 13.12 & 13.81 \\
\hline
\end{tabular}

\section{2 枯水期平均水位}

枯水期 (10 月至次年 3 月) 多年平均水位为 $11.81 \mathrm{~m}$ (表 2 ), 最大值为 $13.78 \mathrm{~m}$ (1997 年), 最小值为 $9.61 \mathrm{~m}$ (2007 年).

表 $21952-2010$ 年都昌水文站枯水期平均水位多年变化统计 $(\mathrm{m})$

Tab. 2 Statistics of mean water level in low-water level period at Duchang Station during 1952-2010

\begin{tabular}{cccccccc}
\hline 时间 & $1952-1960$ & $1961-1970$ & $1971-1980$ & $1981-1990$ & $1991-2000$ & $2001-2010$ & $1952-2010$ \\
\hline $1-3$ 月 & 11.48 & 10.83 & 11.26 & 11.52 & 11.75 & 10.78 & 11.27 \\
$10-12$ 月 & 12.34 & 12.85 & 12.37 & 13.03 & 12.51 & 11.24 & 12.39 \\
10 一次年 3 月 & 11.90 & 11.83 & 11.83 & 12.34 & 12.11 & 10.88 & 11.81 \\
\hline
\end{tabular}

\section{3 枯水出现时间及其变化}

统计表明,枯水最早出现在 8 月 20 日 (2006 年),最迟出现在 12 月 25 日 (1953 年). 1952-2010 年历年 枯水出现时间经历了 “先提前后推迟再提前” 的变化过程, 总体上呈提前趋势, 平均约为 $0.22 \mathrm{~d} / \mathrm{a}$. $2000 \mathrm{~s}$ 枯 水出现时间最早 (10 月 25 日,表 3 ), 比近 $60 \mathrm{a}$ 枯水平均出现时间偏早 $10 \mathrm{~d}$.

表 $31952-2010$ 年都昌水文站枯水出现时间多年变化统计

Tab. 3 Statistics of low-water level occurring time at Duchang Station during 1952-2010

\begin{tabular}{|c|c|c|c|c|c|c|c|}
\hline 出现时间 & $1952-1960$ & $1961-1970$ & $1971-1980$ & $1981-1990$ & $1991-2000$ & $2001-2010$ & $1952-2010$ \\
\hline 枯水出现时间 & 11 月 2 日 & 11 月 14 日 & 10 月 29 日 & 11 月 18 日 & 11 月 4 日 & 10 月 25 日 & 11 月 4 日 \\
\hline 中度枯水出现时间 & 11 月 23 日 & 12 月 4 日 & 11 月 20 日 & 11 月 29 日 & 11 月 16 日 & 11 月 6 日 & 11 月 21 日 \\
\hline
\end{tabular}

\section{4 枯水持续时间}

多年平均枯水持续时间 $144 \mathrm{~d}$,最长 $294 \mathrm{~d}$ (2006 年), 最短 $28 \mathrm{~d}$ (1997 年). 以年代段统计, 2000s 最长, 达 $175 \mathrm{~d}$ (表 4), 是这 $10 \mathrm{a}$ 枯水出现时间最早 (表 3) 与结束时间最迟 (表 4)共同导致的. 自 1997 年起,枯水持 
续时间明显增多, 达 $9.75 \mathrm{~d} / \mathrm{a}$.

表 4 1952－2010 年都昌水文站枯水持续时间多年变化统计

Tab. 4 Statistics of low-water level duration at Duchang Station during 1952-2010

\begin{tabular}{|c|c|c|c|c|c|c|c|}
\hline & $1952-1960$ & $1961-1970$ & $1971-1980$ & $1981-1990$ & $1991-2000$ & $2001-2010$ & $1952-2010$ \\
\hline 枯水持续时间/d & 145 & 148 & 146 & 113 & 130 & 175 & 144 \\
\hline 枯水结束日期 & 3 月 29 日 & 4 月 10 日 & 3 月 26 日 & 3 月 10 日 & 3 月 18 日 & 4 月 26 日 & 3 月 30 日 \\
\hline
\end{tabular}

\section{3 讨论}

鄱阳湖枯水的形成与变化, 与五河人湖水量和长江来水量密切相关. 枯水位变化与 $10-12$ 月长江来水 量变化以及与 $12 \mathrm{~m}$ 高程以下容积变化过程的反向对应关系在 2002 年以后较好,说明鄱阳湖年最低水位的 变化主要由 10-12 月五河人湖水量控制 (图 1a),2002 年以后湖盆底部容积加大对年最低水位的下降起了 显著作用. 而枯水变化与 10 月至次年 3 月五河人湖水量的反向对应关系较好,与 $12 \mathrm{~m}$ 高程以下容积的正向 关系在 2002 年以前不明显,在 2002 年以后显著 (图 1b), 表明鄱阳湖枯水期平均水位和枯水持续时间主要 受长江同期来水量控制, 五河同期人湖水量的影响也较大,近 $10 \mathrm{a}$ 来湖盆底部容积加大对降低枯水期水位、 加长枯水持续时间起了不可忽视的作用.
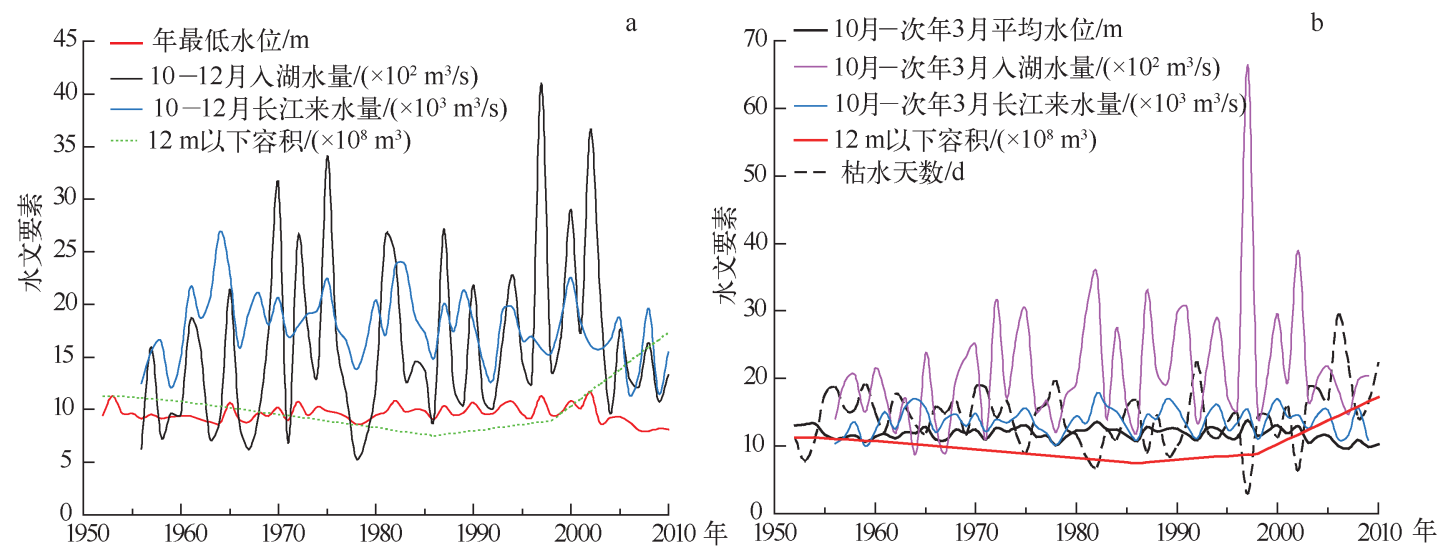

图 1 鄱阳湖枯水与其它江、湖水文要素多年变化对比

Fig. 1 Comparison on low-water level between Lake Poyang and other lakes-river regimes

气候变化模拟研究表明,鄱阳湖流域降水量与径流量自 $1960 \mathrm{~s}$ 至今经历了先升后降的过程 ${ }^{[7-9]}$, 同期内 鄱阳湖枯水变化与此基本一致. 2002 年以后鄱阳湖年最低水位变化与 $12 \mathrm{~m}$ 高程以下容积变化的对应关系 较好,而 $12 \mathrm{~m}$ 高程以下容积变化不仅与湖盆内大量采砂有关, 与流域产沙减少和五河人湖沙量下降也密切 相关, 其中流域产沙减少是水土保持和植树造林作用的结果, 五河人湖沙量下降是新建水库增多、拦沙能力 增强的结果. 因此,鄱阳湖枯水变化是气候变化、下垫面土地利用方式以及人类活动等综合影响的结果. 值 得注意的是,自 2002 年起鄱阳湖枯水位大幅下降、枯水出现时间明显提前、枯水持续时间显著加长, 与鄱阳 湖大量采砂时间一致, 说明近 $10 \mathrm{a}$ 来鄱阳湖枯水加剧与人类采砂等活动密切相关, 是采砂等人类活动改变 湖盆形态水文效应的突出表现. 过度采砂造成江河湖泊低水位变化,对水资源持续利用和生态环境保护造 成不良影响 ${ }^{[10-11]}$. 近 $10 \mathrm{a}$ 来鄱阳湖超量采砂, 在一定程度上放大了枯水期五河人湖水量减少和长江来水下 降对加重枯水程度的作用.

三峡工程自 2003 年起进人试运行阶段,分析表明三峡水库调度运行对鄱阳湖枯季水位的影响, 主要在 以下两个方面:一是三峡水库蓄水期间 (9 月 15 日-10月 31 日), 长江中下游来水量减少,促使鄱阳湖湖水 下泄速度加快, 鄱阳湖水位下降速度随之加快, 水位下降幅度加大;二是三峡水库补水期间 (12 月 1 日至次 
年 3 月 31 日), 长江中下游来水量增加, 长江九江段水位下降速度减缓, 对鄱阳湖水位下降起到一定缓冲作 用. 从 2003-2011 年还原计算结果看,三峡水库调度运行对鄱阳湖枯季水位的影响具有以下规律: 1 )三峡 水库蓄水对鄱阳湖水位下降所起的作用受期间鄱阳湖流域和长江中下游地区降水多少制约,降水多则三峡 水库蓄水对鄱阳湖水位下降所起的作用小,如 2008 年;降水少则三峡水库蓄水对鄱阳湖水位下降所起的作 用大,如 2006 年. 2) 三峡水库补水对鄱阳湖水位下降所起的缓冲作用仅限于鄱阳湖北部人江水道, 星子水 位站以南缓冲作用不明显. 由此可见, 三峡水库调度运行对鄱阳湖枯季平均水位单向下降的作用不显著, 对 鄱阳湖年最低水位下降不起作用. 也就是说, 三峡水库调度运行不是导致鄱阳湖枯水变化的主要原因.

鄱阳湖枯水变化主要由流域内的降水变化决定,也与湖盆形态变化密切相关.气候变化预测表明,未来 十几年内鄱阳湖流域冬半年降水和径流将维持减小态势 ${ }^{[9]}$, 加上三峡工程运用将导致长江中下游干流河床 开始冲刷 ${ }^{[12]}$, 湖口附近水位随之下降, 加大鄱阳湖出流速度, 拉低湖面水位. 在两方面的共同作用下, 未来十 几年内鄱阳湖枯水可能继续维持加剧局面, 应引起社会各界的足够重视.

\section{4 参考文献}

[1] 闵 寒. 鄱阳湖水位变化规律的研究. 湖泊科学, 1996, 7(3): 215-221.

[ 2 ] 闵 寒. 鄱阳湖退水规律初步探讨. 海洋湖沼通报, 1989, (4) : 30-34.

[ 3 ] 闵 寒, 汪泽培. 鄱阳湖近 600 年洪水规律的分析. 湖泊科学, 1994, 5(4) : 375-383.

[ 4 ] 闵 寒. 20 世纪 90 年代鄱阳湖洪水特征的分析. 湖泊科学, 2002, 13(4) : 323-330.

[ 5 ] 闵 骞, 闵 聑. 鄱阳湖区干旱演变特征与水文防旱对策. 水文, 2010, 30(1): 84-88.

[ 6 ] 闵 骞. 论鄱阳湖生态经济区水资源保障体系的构建. 服务发展方式转变. 促进中部科学崛起- 2010 年促进 中部崛起专家论坛文集. 北京: 中国科学技术出版社, 2010: 47-48.

[ 7 ] 叶许春, 张 奇, 刘 健等. 气候变化和人类活动对鄱阳湖流域径流变化的影响研究. 冰川冻土, 2009, 31(5): 835-842.

[ 8 ] 蔡玉林, 孙国清, 过志峰等. 气候变化对鄱阳湖流域径流的影响模拟. 资源科学, 2009, 31(5): 743-749.

[ 9 ] 郭 华, 殷国强, 姜 肜. 未来 50 年鄱阳湖流域气候变化预估. 长江流域资源与环境, 2008, 17(1) : 73-78.

[10］陆永军, 贾良文, 莫思平. 珠江三角洲网河低水位变化. 北京: 中国水利水电出版社, 2008: 200-238.

[11] 王西琴, 刘 斌, 张 远. 环境流量界定与管理. 北京: 中国水利水电出版社, 2010: 114-143.

[12］卢金友, 黄 悦. 三峡工程运用后长江中下游干流冲淤变化对防洪工程的影响研究. 纪念 “ 98 ”抗洪十周年学术 研讨会优秀文集. 郑州: 黄河水利出版社, 2008: 147-152. 